\title{
ANALYSIS OF GLOBAL INVESTMENT CAPITAL FLOWS
}

\author{
Olekcandr Petrashko \\ ICU Group \\ 19/21 B.Hmelnutskogostr., Kyiv, Ukraine, 01030 \\ 7alexander7@gmail.com
}

\begin{abstract}
The paper is devoted to the study of the dynamics and movement character of global investment capital flows. According to expert data and reports of EBRD, OECD, WB, IMF, UNCTAD, MIGA, CreditSuissethere was realized the analysis of direct foreign investments in countries with the developed economy and developing ones. The short-term prognoses of the movement character of global investment flows of direct and portfolio investment by regions and in the whole were estimated. The high dynamics of renewal of global direct and portfolio investment flows in 2015 and their unessential decrease by $10-15 \%$ in the short outlook was determined.

The modern global investment tendencies were systematized by regions: Europe, Northern America, Eastern Europe, Asia, Latin America, Near East and Northern Africa, Southern Africa. As a result, it was determined, that the decrease of investment flows dynamics is expected in Europe and Northern America, although Europe remains the most region-investor, and the Northern America demonstrates the fourfold growth of the capital inflow. For developing countries in the middle-term prospect will be typical tendencies of portfolio investments outflow. The deceleration and essential shortening of volumes of direct and portfolio investment flows is typical mainly for Africa and Eastern Europe. Asia is the exclusion, where the dynamics of capital inflow growth returns, and China that is the third investor in the world for today.

Periods of global investment flows deceleration and their modern tendencies were separated and characterized.
\end{abstract}

Keywords: global investment tendencies, global investment flows, direct foreign investments, portfolio investments.

\section{Introduction}

The global process of the economic growth renewal continues but the rates of this growth are slow and unstable. The optimism of main economic indices of developed countries is proved by experts as to the economic development renewal, favored by the stabilization of prices for oil, decrease of the capital outflow from China and regulative national policies of central banks. But there are essential threats of economy growth rates decrease in the world.The assessments of experts note new volatility episodes on world markets of assets, some weakening of the economic growth dynamics in developed countries and conservation of obstacles for its growth in countries with the forming market and in ones with lower incomes.

The one of most important causes of the decrease of economic growth rates in the world - the demand decrease, especially for investments. It remains weak throughout the world, but mostly in countries-exporters of exchange goods, which trade conditions were worsened radically. The weak demand for investments is connected with the deceleration of the international trade growth taking into account the important role of investment and intermediate goods in it.

\section{Analysis of literary data and statement of problem}

For today in scientific literature is studied the wide spectrum of questions of the analysis of global capital investment flows. Experts analyze most important economic risks, namely the renewal of financial disturbances that weaken confidence and demand as a result of the negative feedback. Several authors at studying investment tendencies in 2002-2004 name them a triumph of optimists and irrational optimism [1,2]. Despite the renewal of asset prices in last years, financial conditions of the USA, Europe and Japan in whole become more rigid since the middle of 2014. In other countries financial conditions become more regulated [3].

Analytic reviews and reports of international institutions, devoted to the assessment of world economy development prospects, elucidate investment tendencies in the close connection with macroeconomic development parameters [4-6]. Experts of the analysis of world portfolio investments accent the diversification of assets classes [7-9]. 
Several native researchers of the analysis of world investment flows mainly separate the one type of investments (portfolio or direct investment) [10] or study a concrete regional section [11], limiting the picture of the complex analysis of tendencies.

Despite the large number of studies as to different aspects of global investment flows, questions of direct and portfolio investment flows by regions of the world are always topical for new researchers in the context of the determination of their deceleration periods and revelation of their repeats cyclicity. Accents of such assessments for the author research are made in the vector of capital movement by world regions and factor influence on its character.

\section{Aim of research}

The aim of the work is a characteristic of modern tendencies of capital global investment flows movement. The following tasks were set for attaining this aim:

- to analyze the dynamics and character of global tendencies of direct and portfolio investments inflow and outflow by groups of countries;

- to systematize modern global investment tendencies by world regions;

- to characterize periods of global investment flows deceleration.

\section{Materials and methods}

The study was realized on the base of statistical data and reports, information materials, analytic reviews and expert estimations of EBRD, OECD, WB, IMF, UNCTAD, MIGA, CreditSuisse. In the process of solving tasks, set in the study general scientific and special methods were used. Thus, methods of economic analysis and synthesis were used for studying the evolution of priority directions of global capital investment flows; methods of the system generalization - at formulating conclusions of the study; classification-analytic methods - for systematization and structurization of direct and portfolio investments flows.

\section{Results}

According to expert estimations of prospects of the development of the world economy and finances for 2008-2016, the descendent deceleration of volumes of direct and indirect portfolio investments was fixed [3, 5, 6, 12-20].

According to data of the department of investments and enterprises UNCTAD, UNO, global investment tendencies are characterized with the high dynamics of direct foreign investment (DFI) flows renewal in 2015-2016 [12].

Thus, in 2015 DFI global flows grew by $38 \%$ that is the highest level after the global financial-economic crisis of 2008-2009. Such situation is explained, first of all, by the abrupt decrease of the cost of theconsolidation and absorptions, which sum was in 2015 year 721 bil USA dol that is by $66 \%$ more than in 2014. Without takinginto account changes in the configuration of transnational corporations, the increment of DFI global flows may be considered as moderate, it is near $15 \%$. The high level of the sum of declared investments in new projects, namely 766 bil of USA dol may be also noted [12]

But such increment of global DFI flows didn't result in the even distribution of production potential by groups of countries and regions of the world. The comparison of the dynamics of the global DFI inflow structure by groups of countries allows to make a conclusion about its essential differences between groups of countries and regions in 2015. Thus, the share of developed countries grew from $41 \%$ in 2014 to $55 \%$ in 2015 .

The change of tendencies of the last 5 years, when developing countries and ones with the transitional economy were main receivers of global DFI took place. The change of the global tendencies of the structure of DFI global inflow in the side of developed countries increased almost twice (by $84 \%$ ) up to 962 bil USA dol comparing with 522 bil USA dol in 2014 [12].

The global DFI inflow in Northern America reached in 2015429 bil USA dol that exceeded their record level in 2000. The most inflow was demonstrated by the USA - almost fourfold growth. For developed European countries, the high growth of DFI inflow also took place, namely up to 504 bil USA dol that is $29 \%$ of the whole global DFI inflow.This growth is caused by the essential 
increase of DFI import in Ireland, Netherland and Switzerland. For France and Germanyin 2015 is typical the abrupt growth of DFI after the decrease in 2014. The global DFI inflow in the United Kingdom decreased to 40 bil USA dol. But the United Kingdom remains the one of most receivers of global DFI in Europe [12].

In developing countries in 2015 was reached the new maximum DFI inflow - 765 bil USA dol that demonstrated the increment by $9 \%$ comparing with 2014.The exclusion is only the financial center of the Caribbean basin. The inflow in Africa, Latin America and Caribbean region decreased in 2015 by 54 bil USA dol that demonstrates the decrease by $7 \%$ comparing with 2014. The dynamic DFI inflow in Egypt favored their increased in the Northern Africa by $9 \%$ in 2015 comparing with 2014 and was 12,6bil USA dol [12].

The region of the Western, Central and Eastern Africa demonstrates in 2015 the decrease of DFI inflow comparing with 2014 respectively by $18 \%$ (to 9,9 bil USA dol), by $36 \%$ ( to 5,8 bil USA dol) and by $2 \%$ (to 7,8 bil USA dol). In the region of the Southern Africa the global DFI inflow increased by $2 \%$ up to 17,9 bil USA dol [12].

Asian developing countries remains the region-receiver of most DFI inflow in the world that exceed a half of trillion USA dollars and demonstrates the growth in 2015 by $16 \%$ comparing with 2014. Such growth is conditioned by DFI growth in the Eastern Asia by $25 \%$ up to 322 bil USA dol at the expanse of great investments in the capital stock, connected with the corporative restructurization in Hong Kong (China) and the dynamic DFI inflow in the China service center. The South-Eastern Asia region demonstrated in 2015 the abrupt increase of DFI inflow in countries with a low income, namely Vietnam, Myanmar and low dynamics of DFI inflow in countries with the higher level of incomes, namely, Singapore, Indonesia and Malaysia. The DFI inflow in the Southern Asia region reached in 201550 bil USA dol, the growth by $22 \%$ comparing with 2014. In 2015 took place the decrease of DFI in Western Asia by $2 \%$ to 42 bil USA dol. The exclusion is Turkey, that demonstrated the DFI inflow growth [12].

The global DFI inflow in the region of the Latin America and Caribbean one in 2015 remains at the same level that in 2014. At the same time the region of the Central and Southern America demonstrate the different dynamics: Central America - the increase of DFI inflow by $14 \%$, and Northern America - the decrease of DFI inflow by $6 \%$ [12].

Developed countries, as earlier, are a half of 10 countries-receivers of most DFI volumes. Top-20 of countries-most world receivers of DFI in 2014-2015 in bil USA dol. Among countries-leaders that are developing in this list are Brazil, India, Chile [12].

In countries with the transitional economy the DFI inflow in 2015 decreased by $38 \%$. Its dynamics by groups of countries was different depending on national features of economic state and DFI regulation policies. Thus, in South-Eastern Europe the DFI flow increased by $6 \%$ because of the improvement of the macroeconomic conjuncture and the process of joining the EU by a series of countries. A DFI inflow in countries of the Community of independent states (CIS) and Georgia, on the contrary, decreased by $42 \%$ because of the decrease of the conjuncture of internal markets, legislative changes and geopolitical tension in the region. The DFI inflow in the Russian Federation decreased to 9,8 bil USA dol [12].

The DFI inflow in least developed countries (LDC) increased by $33 \%$, and in small insular developing countries SIDC decreased by $32 \%$ and developing countries without an exit to sea (DCWES) decreased by $18 \%$ [12].

After the decline of the removal of global DFI from developing countries in 2012-2014 in 2015 the increase of DFI removal from developed countries by $33 \%$ to 1.1 trln USA dol was observed. Developed countries in 2015 had $72 \%$ of the global DFI removal that demonstrates the growth of this index by $61 \%$ comparing with 2014. But if compare it with 2007 that was a beginning of the almost seven-year global removal of DFI from developed countries, the aforesaid growth in 2015 remains by $40 \%$ lower than the maximum, reached in 2007. The most world region-investor in 2015 became Europe with 576 bil USA dol. Farther in the group of most regions-investors are USA, Japan and China [12].

In 2015 was kept the global tendency of the decrease of DFI removal from developed countries and ones with the transitional economy. BNP DFI of countries with the transitional economy 
was decreased more than in half, namely to 31 bil USA dol. It is connected mainly with geopolitical risks and decrease of prices on raw material and devaluation of national currencies.

The country, excluded from this tendency, is China. The DFI removal from it remains high, being increased from 123 bil USA dol (2014) to 128 bil USA (2015). In 2015 China was the third investor in the world [12].

The removal of DFI from Africa countries decreased by $25 \%$ to 11,3 bil USA dol. The decrease of investment flows from the Southern Africa, Nigeria and Angola took place at the expanse of the decreased prices on raw material, decrease of demand from main trade partners and decrease of national currencies rates.

The Asian region of developing countries demonstrated in 2015 the decrease of the DFI removal by $17 \%$ to 332 bil USA dol, but despite this fact it remains the third in the rating. As it was already noted, the exclusion is China and Thailand. The removal of DFI from Hong Kong in 2015 decreased more than twice to 55 bil. USA dol, that is explained by the great corporative restructurization. The decrease of DFI from the South-Eastern Asia decreased by $11 \%$, from India - more than 1/3. But the region of the Western Asia demonstrated in 2015 the increase of DFI removal by $54 \%$ comparing with 2014 and reached 31 bil USA dol. [12].

The DFI removal from the region of the Latin America and Caribbean basin increased in 2015 by $5 \%$ comparing with 2014. The leaders are Brazil - DFI removal increase in 2015 by $38 \%$ because of mainly essential decrease of reverse investments of Brazilian branches of foreign companies and Chile - respectively by $31 \%$ to 16 bil USA dol [12].

Comparing with 2014, the volume of quarterly investment flows by structures of special destination (SSD) in 2015 abruptly increased and reached levels of 2012-2013. The distinct instability of investment flows that were abruptly replaced by the great pure outflow in the last quarter of 2015 after the essential inflow in first three ones must be noted. Despite the deceleration of offshore financial flows in 2015, the share of incomes from investments in offshore jurisdictions is high. That is why the gap between places of incomes and production investments that results in essential losses of tax incomes causes serous worry of directive organs.

According to expert estimations of the dynamics of capital flows in countries with the forming market for 2007-2015, the essential deceleration of the pure capital inflow was conditioned by both inflow and outflow of the capital. According to observation, the deceleration in this period touched near three forth of countries with the forming market and widely enclosed different regions [5].

For last several decades capital inflows in countries with the forming market demonstrate the exact cyclicity, and previous decelerations of early 1980 and late 1990 were greater comparing with the current episode. The current episode differs by the fact that from early 1990 in countries with the forming market took place serious structural and political changes. Today these countries, according to expert estimations, are much more integrated in global financial markets. Countries with the forming market try to diversify their portfolios and involve external assets. As a result, the capital outflow becomes the more and more important component of the general dynamic of the capital movement. At the same time these countries have now much more essential currency reserves that may be used as a buffer at crisis periods.

The decrease of the demand for assets of countries with the forming market also influenced the deceleration of the capital inflow growth [5]. Such decrease was essentially abrupt in the second half of 2015: first after the world economic crisis took place pure sales of portfolio assets by foreign investors in countries with the forming market. The one of main factors of the change of the dynamics of total flows in countries with the forming market in this period was changes in the payment balance of China. Based on changing expectations as to the exchange rate of yuan to dollar, Chinese companies have made essential payments for the external debt extinction last summer that led to the negative level of the capital inflow. And China residents increased volumes of foreign assets acquirement, having increased the capital outflow. Under conditions of the rigid regulation of the exchange rate both these operations led to the essential decrease of currency reserves of China. Among market countries and developing ones reserves decreased in the several oil exporters, who use the exchange rate associating, because abrupt 
decrease of incomes from oil favored the decrease of the balance of the account of current operations [5].

The inflow of investments, analogous to the participation in the capital is defined as a DFI (direct foreign investments) and portfolio investments inflow. If consider only the gross capital inflow, the continuous deceleration begins in 2014 and intensifies in 2015. The dynamics of direct and portfolio investments in analytic groups of countries with the developed economy and developing ones is presented on Fig. 1.

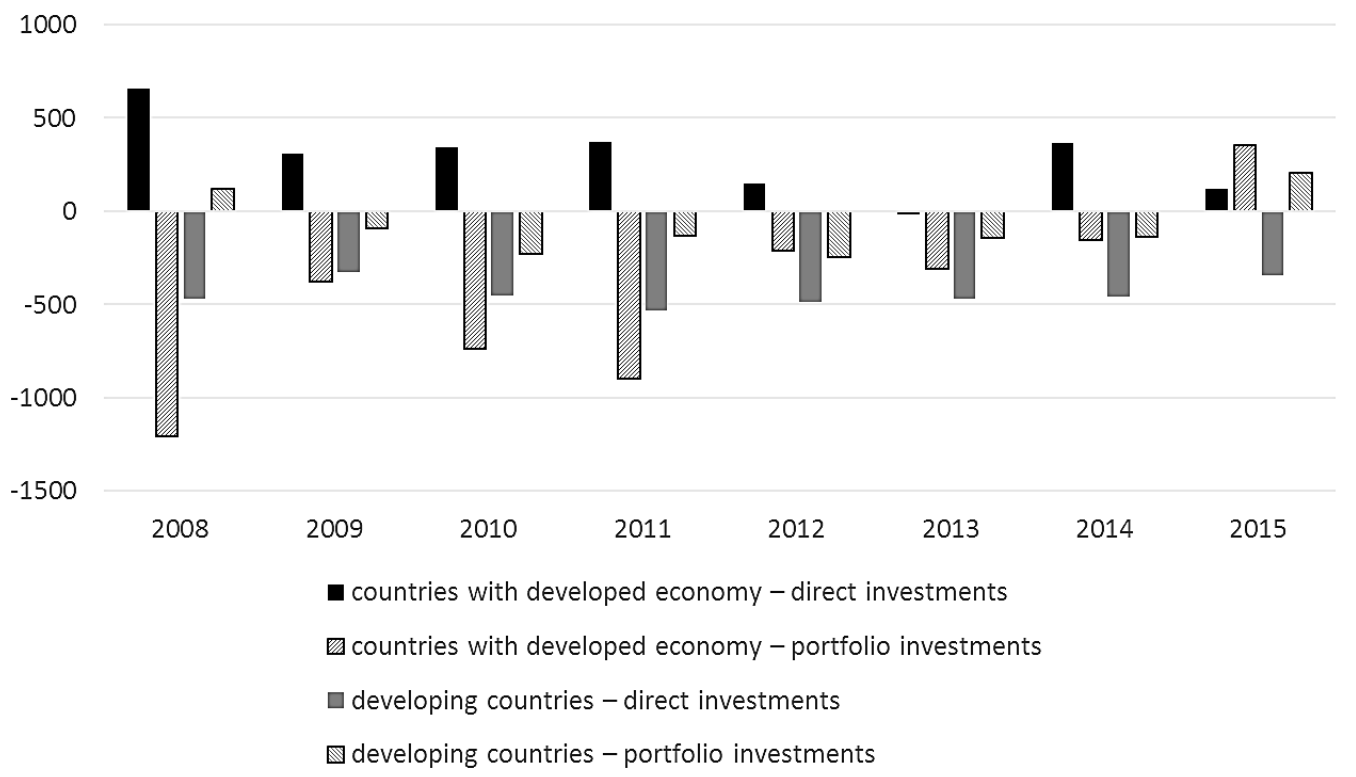

Fig. 1.The dynamics of direct and portfolio investment in the world, 2008-2015 Constructed on the base of [5]

According to the data of Eurostat, OECD, MB, IMF, UNCTAD UNO, Credit Suisse, only near 10 countries with the transitional economy and developing ones are importers of direct and portfolio investments [3-6, 12-22].

In 80-90 years of XX century was observed the abrupt growth of portfolio investments in the world [7, 18].Such situation is explained by the decrease of investment volumes from Japan, USA, Latin America and South-Eastern Asia. Portfolio investment flows between European countries with the developed economy and USA are more typical for XXI century.

According to estimations of the dynamics of direct and portfolio investments in the world, one can make a conclusion that the specific weight of direct investments in the economy of developing countries (if include in this group India, Brazil, Korea, Singapore and China) is higher than the part of portfolio investments [5]. The completely other tendency is typical for countries with the developed economy: in Asia - Japan, in the Northern America - USA and Canada, in Europe Germany, Great Britain - the predominationof the specific weight of portfolio investments over the direct financing takes place. The deceleration of 2010-2015 reflects the certain combination of inflow decline and outflow increase of all four types of assets, noted in the payment balance: direct foreign investment (DFI), portfolio investments in the capital, portfolio investments in debt instruments and "other investments" (including flows of bank assets), despite the fact that in 2015 the outflow increase returned back [5].

Top-10 of economies by assets of portfolio investments in 2016 (June): USA - 9,53, Japan - 3,97, Luxembourg - 3,80, Great Britain - 3,63, Germany - 3,08, France - 2, 61, Netherland - 1,79, Italy - 1,29, Switzerland - 1,28, Hong Kong (China) - 1,27 tril USA dol[9].

Top-10 of global directions by assets of portfolio investments in 2016 includes: Turkey $28 \%$ of the general volume of foreign investments, Germany - $9 \%$, Belgium, Italy and Russian Federation - by $7 \%$, Netherland - 6\%, Greece $-5 \%$, Brazil, Luxembourg and France - by $4 \%$ [9]. 
The characteristics of periods of the global investment flows deceleration in 1981-2015 is presented in Table 1.

Table 1

Periods of global investment flows deceleration, 1981-2015

\begin{tabular}{|c|c|c|c|}
\hline \multirow{2}{*}{ Characteristics } & \multicolumn{3}{|c|}{ Periods of capital investment flows deceleration } \\
\hline & 1981-1988 & 1995-2000 & 2000-2015 \\
\hline Node influence & Debt crisis of developing countries & Asian crisis & $\begin{array}{l}\text { Decline of economic develop- } \\
\text { ment. Geopolitical events }\end{array}$ \\
\hline $\begin{array}{l}\text { List of countries } \\
\text { that endured crises }\end{array}$ & $\begin{array}{l}\text { Korea, Philippines (2), Costa Rica, } \\
\text { Poland, Shri Lanka, Thailand (2), } \\
\text { Argentina, India, Mexico, Roma- } \\
\text { nia, Brazil, Chile, Ecuador, Uru- } \\
\text { guay, Southern Africa, Paraguay }\end{array}$ & $\begin{array}{l}\text { Bulgaria, Albania, Croatia, Slove- } \\
\text { nia, Argentina (2), Mexico, Korea, } \\
\text { Thailand, Armenia, Indonesia, } \\
\text { Moldova(2), Ukraine, Brazil (2) Ec- } \\
\text { uador, Turkey, Uruguay, Paraguay }\end{array}$ & $\begin{array}{l}\text { Ecuador, Hungry, Latvia, } \\
\text { Turkey, Ukraine (2), Armenia, } \\
\text { Byelorussia, Georgia, Romania, } \\
\text { ShriLanka, Moldova, Albania }\end{array}$ \\
\hline $\begin{array}{l}\% \text { deceleration of } \\
\text { capital flows }\end{array}$ & $-2,4 \%$ & $3,1 \%$ & $-4,8 \%$ \\
\hline $\begin{array}{l}\% \text { of countries with } \\
\text { decelerated ratio of } \\
\text { pure capital to DGP }\end{array}$ & $70 \%$ & $65 \%$ & $76 \%$ \\
\hline
\end{tabular}

Note: (2) - country endured 2 crises during the determined period. Constructed by the author on the base of [1-25]

As a result of the study 3 periods of global investment flows deceleration were separated. The last one, namely 2000-2015 is characterized by the deepest deceleration: capital flows deceleration to $-4,8 \%$ and $76 \%$ countries with decelerated ratio of the pure capital to GDP.

\section{Discussion of results}

The study of the dynamics and character of the movement of global capital investment flows is a part of the review of modern investment theories in the world. Its further deepening is planned, namely in the part of systematization of modern global investment tendencies by regions of the world. The characteristic of periods of the global investment flows deceleration and review of their tendencies will be used in the inter-market analysis of global investment flows.

\section{Conclusions}

As a result of this research the high dynamics of the renewal of global investment flows of direct and portfolio investments in 2015 and their unessential decrease by $10-15 \%$ in the short term prospect were increased. The inessential growth of DFI in 2018 must be expected.

Countries with the developed economy in nearest periods will be at the stage of the slow renewal of the economic growth thatis the growth of investment flows. As a result of the systematization of modern global investment tendencies was determined that: The deceleration of the dynamics of the investment flows growth in the short-term prospect is expected for Europe and Northern America, although Europe remains the most region-investor, and the Northern America demonstrates the fivefold growth of the capital inflow.

The other situation for developing countries it is more difficult for them to restore rates of the economic growth because of different factors. In the middle-term prospect tendencies of the portfolio investments outflow will be typical for them. The deceleration and essential decrease shortening of volumes of direct and portfolio investment flows is typical mainly for Africa, Latin America and Eastern Europe. The exclusion is Asia, where takes place the return of the capital inflow dynamics and China that is the third investor in the world for today. 
There were also separated periods of the global investment flows deceleration: 1981-1988, 1995-2000 and 2000-2015, which node causes were geopolitical events, decline of the economic development, crises of stock markets and debt crises. The greatest by $\%$ of the capital flows deceleration was the one of 2000-2015-4,8\% deceleration and $76 \%$ of countries, in which the ratio of the pure capital to DGP decelerated. That is why for restoring global investment flows, world states must form their policies to favor the investment climate improvement and investing process liberalization.

\section{References}

[1] Elroy, D., Marsh, P., Staunton, M. (2002). Triumph of the Optimists: 101 Years of Global Investment Returns, New Jersey: Princeton University Press

[2] Dimson, E., Marsh, P., Staunton, M. (2004). Irrational Optimism. Financial Analysts Journal, 60 (1), 15-25. doi:10.2469/faj.v60.n1.2589

[3] World Investment Report 2016: Reforming International Investment Governance (2016). Available at: http://unctad.org/en/PublicationsLibrary

[4] Godovoj otchet MVF - 2016: Sovmestnyj poiskreshenij (2016). Available at: http://www.imf. org/external/russian/pubs/ft/ar/2016/pdf/ar16_rus.pdf

[5] MVF: Perspektivy razvitija mirovojj ekonomiki: slishkom dolgij period slishkom medlennogorosta (2016). Vashington. Available at: https://www.imf.org/external/russian/pubs/ft/weo/2016/01/ pdf/textr.pdf

[6] Godovoj otchet MVF-2015: Reshenie problem sovmestnymi usilijami (2016). Available at: https:/www.imf.org/external/russian/pubs/ft/ar/2015/pdf/ar15_rus.pdf

[7] Martynov, A. (2015). Dohodnost' akcij i obligacij po stranam mira. Available at: http://activeinvestor.pro/dohodnost-aktsij-i-obligatsij-po-stranam-mira/

[8] EBRD:Transition for all: Equal opportunities in an unequal world TRANSITION REPORT 2016-17. Available at: http://2016.tr-ebrd.com

[9] IMF Data access to macroeconomic and financial data: Coordinated Portfolio Investment Survey (CPIS). Available at:http://data.imf.org/?sk=B981B4E3-4E58-467E-9B90-9DE0C3367363

[10] Yosypenko, O. A. (2016). Analiz vykorystannya portfel'nykh investytsiy u zabezpechenni ekonomichnoho rozvytku. Upravlinnya rozvytkom, 2 (184), 89-95.

[11] Konotop, H. V. (2014). Osnovni napryamky innovatsiynoho rozvytku v konteksti zaluchennya zovnishn'oho finansuvannya transformatsiynykh ekonomik. Ekonomichnyychasopys - XXI, 3-4 (2), 8-11.

[12] JuNKTAD OON: Doklad o mirovyh investicijah za 2016 god «Grazhdanstvo investorov: vyzovy politiki». (2016). Available at: http://unctad.org/en/PublicationsLibrary/wir2016_Overview_ru.pdf

[13] The World Bank Annual Report 2016. (2016). Available at: http://www.worldbank.org/en/about/ annual-report

[14] Godovoj otchet Mnogostoronnego agentstva po investicionnym garantijam, MIGA - 2015. (2015). Available at: https://www.miga.org/documents/russian_final.pdf.

[15] Doklad o perehodnom processe za 2015-2016: Tendencii i povyshenie kapitalizacii. (2016). Available at: http://www.ebrd.com/...pdf-transition-report-201516-russian-private-equity.pdf.

[16] Doklad po voprosam regional'noj ekonomiki. Available at: http://www.imf.org/external/russian/ pubs/ft/weo/2016/01/pdf/textr.pdf

[17] Credit Suisse: Global Investment Returns (2017). Available at: https://publications.credit-suisse. com/tasks/render/file/?fileID=B8FDD84D-A4CD-D983-12840F52F61BA0B4

[18] Credit Suisse: Global Investment Returns (2015). Available at: https://publications.credit-suisse. com/tasks/render/file/?fileID=AE924F44-E396-A4E5-11E63B09CFE37CCB 
[19] Credit Suisse: Global Investment Returns. (2016). Available at: https://www.credit-suisse.com/ corporate/en/media/news/articles/media-releases/2016/02/en/credit-suisse-global-investment-returns-yearbook-2016.html

[20] Credit Suisse: Global Investment Returns. (2016). Available at: http://pangeafamilyoffices.com/ getattachment/886b62bd-2fcf-4d76-af0e-1bcccb893ddb/2016\%20Credit\%20Suisse\%20Global\%20Investment\%20Returns.aspx

[21] About World Bank Green Bonds. Available at: http://treasury.worldbank.org/cmd/htm/WorldBankGreenBonds.html

[22] About World Bank Treasury. Available at: http://treasury.worldbank.org/bdm/htm/risk_financing.html

[23] Elroy, D., Marsh, P., Staunton, M. (2016). Credit Suisse Global Investment Returns Yearbook 2016. Zurich: Credit Suisse Research Institute.

[24] Elroy, D., Marsh, P., Staunton, M. (2017). The Dimson-Marsh-Staunton Global Investment Returns Database (the "DMS Database"). Morningstar Inc.

[25] Mitchell, B. R. (1992). International Historical Statistics Europe 1750-1988. doi:10.1007/978-1$349-12791-7$ 